\title{
Activity of Endodontic Antibacterial Agents Against Selected Anaerobic Bacteria
}

\author{
Cláudio Maniglia FERREIRA ${ }^{1}$ \\ Odila Pereira da Silva ROSA ${ }^{2}$ \\ Sérgio Aparecido TORRES ${ }^{2}$ \\ Flaviana Bombarda de Andrade FERREIRA ${ }^{3}$ \\ Norberti BERNARDINELLI ${ }^{3}$ \\ ${ }^{1}$ Department of Endodontics, University of Fortaleza, UNIFOR, Fortaleza, CE, Brazil \\ ${ }^{2}$ Department of Microbiology and Immunology and ${ }^{3}$ Department of Endodontics, \\ University of São Paulo, Bauru, SP, Brazil
}

\begin{abstract}
The antimicrobial activity of substances used as antibacterial agents (solutions of $10 \%$ calcium hydroxide, camphorated paramonochlorophenol - PMCC, 2\% chlorhexidine digluconate and 10\% castor oil plant detergent) on anaerobic bacteria (Fusobacterium nucleatum ATCC 25586, Prevotella nigrescens ATCC 33563, Clostridium perfringens ATCC 13124 and Bacteroides fragilis ATCC 25285), using a broth dilution technique, was evaluated in vitro. For determination of minimum inhibitory and minimum bactericide concentrations (MIC and MBC), two culture broths, Reinforced Clostridial Medium (RCM) and supplemented Brucella, standardized inoculum and serially diluted solutions were used. All antibacterial agents presented antimicrobial activity that varied for different bacteria. There were no differences in the performance of the two broths. Chlorhexidine digluconate was the most effective, with the lowest MICs, followed by castor oil detergent, PMCC and calcium hydroxide. $C$. perfringens and B. fragilis were the most resistant bacteria to all agents.
\end{abstract}

Key Words: endodontics, microbiology, anaerobic bacteria, antibacterial agents.

\section{INTRODUCTION}

In teeth with pulp necrosis and periapical lesions, $90 \%$ of the isolated bacteria are strict anaerobic, with different associations among the species $(1,2)$, although no absolute association has been established between certain species and the signs and symptoms of an infected root canal (3). To eliminate the microorganisms and to obtain regeneration/healing of periapical tissues, combinations of endodontic techniques, such as instrumentation, irrigation/aspiration, dressings and filling of the pulp cavity, are used (4).

Chemical-mechanical treatment of the necrotic root canals alone does not completely clean the canal system. In ramifications and dental tubules, the amount of remaining bacteria is considerable and the use of an intracanal medication is indicated as a dressing to pro- mote their elimination. Ideally, the medication should also reduce periapical inflammation and consequently pain, induce a cure by the formation of hard tissue, control persistent exudation, inhibit osteoclastic activity and prevent, or at least delay, reinfection of the root canal system between sessions (5). None of the antibacterial agents traditionally used as intracanal dressings (camphorated paramonochlorophenol, calcium hydroxide, chlorhexidine, among others) presents all of these properties, justifying research for new agents that, together with consistent antimicrobial activity, are less toxic.

A castor oil plant derived detergent with bacteriostatic activity was developed at the Institute of Chemistry of São Carlos, University of São Paulo (IQSCUSP, Brazil) in 1984. The castor oil plant (Ricinus comunis), a typical vegetable of tropical climates, with great oil-chemical potential, guarantees a wide-scale 
supply of polyols and pre-polymers from fatty acids. The utilization of this detergent for biological use is very recent, and research is still in initial phases, but the results are very exciting, because it seems to be highly biocompatible (6). In an endodontic study (7), the detergent showed antibacterial activity comparable to that of $0.5 \%$ sodium hypochlorite, with a decrease of facultative microorganisms, when used for irrigation in the chemical-mechanical preparation of teeth with necrotic pulp and periapical lesion. Currently, a product with this substance in its composition is commercially available in Brazil (Endoquil, Poliquil Araraquara Polímeros Químicos Ltda, Araraquara, SP, Brazil).

The aim of the present work was to determine the effect of this new substance and other antibacterial agents on representative strains of anaerobic microorganisms frequently isolated from infected canals, as well as of microorganisms commonly used in antibiotic susceptibility testing, using a broth dilution technique. This method was chosen because of the shortage of studies using quantitative techniques of dilution, more suitable than the agar diffusion test to determine the susceptibility of anaerobes (8).

\section{MATERIAL AND METHODS}

The antimicrobial activity of 4 antibacterial agents was determined by the conventional broth macrodilution test (9). The tests were made with reference strains of Prevotella nigrescens (ATCC 33563), Fusobacterium nucleatum (ATCC 25586), Clostridium perfringens (ATCC 13124) and Bacteroides fragilis (ATCC 25285) using $10 \%$ aqueous calcium hydroxide (Biodinâmica, Rio de Janeiro, RJ, Brazil); 2\% chlorhexidine digluconate (F.G.M., Curitiba, PR, Brazil); 10\% castor oil plant derived detergent (kindly provided by Prof. Dr. Gilberto Chierice, IQSC-USP, Brazil), and camphorated paramonochlorophenol (CPMC - Inodon, Porto Alegre, RS, Brazil).

Preparation of the inoculum. Two screw-capped $16 \times 160 \mathrm{~mm}$ pyrex test tubes containing $10 \mathrm{ml}$ of Reinforced Clostridial Medium (RCM-Oxoid, Hampshire, England) or Brucella broth (BD-Difco, São Paulo, SP, Brazil) supplemented with hemin $(5 \mu \mathrm{g} / \mathrm{ml})$ (Sigma, St. Louis, MO, USA) and vitamin $\mathrm{K}_{1}(10 \mu \mathrm{g} / \mathrm{ml})$ (Merck, Darmstadt, Germany) were inoculated with $0.1 \mathrm{ml}$ of the stock, and incubated at $37^{\circ} \mathrm{C}$ in an anaerobic jar (Difco) until growth was evident. Two other 24-h trans- fers under the same conditions were made. After obtaining maximum growth activity, the tubes were read in an Ultrospec 1000 spectrophotometer (Pharmacia, Peapack, NJ, USA) at $540 \mathrm{~nm}$. The cultures were diluted in RCM and supplemented Brucella broths to the turbidity of the $0.5 \mathrm{McF}$ arland standard $\left(10^{8}\right.$ colony forming units - cfu/ml) and then further diluted to the concentration of $5 \times 10^{5} \mathrm{cfu} / \mathrm{ml}$ to be used as inoculum. The standardized inoculum was always up to $30 \mathrm{~min}$ after the adjustment.

Dilution of the agents. In screw-capped 13 x 130 $\mathrm{mm}$ sterile tubes containing $2.5 \mathrm{ml} \mathrm{RCM}$ or supplemented Brucella broth, serial two-fold dilutions of the antimicrobial solutions were prepared and $2.5 \mathrm{ml}$ of inoculum were added. The positive control was a tube containing the standardized inoculum and broth, and the negative control was a tube containing broth plus antimicrobial agents.

For comparison, reading of optical density (OD) of all tubes was done with a spectrophotometer before and after incubation at $37^{\circ} \mathrm{C}$ in anaerobiosis for $48 \mathrm{~h}$ for RCM broth and $96 \mathrm{~h}$ for Brucella broth. Visual reading was also done. The minimum inhibitory concentration (MIC) was read as the lowest concentration producing no visible growth, while the minimum bactericidal concentration (MBC, the lowest concentration resulting in $99.9 \%$ killing rate) was determined by spreading with a Drigalsky loop $25 \mu$ l of material from each negative tube to $52 \times 12 \mathrm{~mm}$ petri plates containing $5 \mathrm{ml}$ of blood RCM agar and incubating at $37^{\circ} \mathrm{C}$ in anaerobiosis for $48 \mathrm{~h}$.

\section{RESULTS}

The MICs and MBCs obtained in RCM and supplemented Brucella broth for each bacteria are reported in Tables 1 and 2. The concentration ranges in $\mu \mathrm{g} / \mathrm{ml}$ for different antibacterial agents and the number of dilutions in the interval between the minimum and maximum values are shown in Table 2. Having as reference the optical densities of positive controls in RCM and Brucella broths for Fusobacterium nucleatum (2,080 and 1,000), Prevotella nigrescens (2,280 and 1,060), Clostridium perfringens (2,190 and 1,300), and Bacteroides fragilis (2,030 and 1,400), it was observed that all antibacterial agents presented some degree of growth inhibition, even at concentrations 2 to 5 times lower than MIC. 
Table 1. MIC and MBC in $\mu \mathrm{g} / \mathrm{ml}$ of the antibacterial agents on anaerobic bacteria in RCM broth and Brucella broth.

\begin{tabular}{|c|c|c|c|c|c|c|c|c|}
\hline \multirow[t]{2}{*}{ Bacteria } & \multicolumn{2}{|c|}{$\mathrm{Ca}(\mathrm{OH})_{2}$} & \multicolumn{2}{|c|}{ Chlorhexidine } & \multicolumn{2}{|c|}{ CPMC } & \multicolumn{2}{|c|}{ Detergent } \\
\hline & MIC & MBC & MIC & $\mathrm{MBC}$ & MIC & $\mathrm{MBC}$ & MIC & $\mathrm{MBC}$ \\
\hline \multicolumn{9}{|l|}{ RCM broth } \\
\hline F.nucleatum & 781.25 & 1562.50 & 0.30 & 1.22 & 340.00 & 680.00 & 98.00 & 196.00 \\
\hline P. nigrescens & 781.25 & 1562.50 & 0.30 & 1.22 & 85.00 & 340.00 & 49.00 & 98.00 \\
\hline C. perfringens & 6250.00 & 6250.00 & 2.44 & 2.44 & 680.00 & 680.00 & 196.00 & 196.00 \\
\hline B. fragilis & 3125.00 & 3125.00 & 9.75 & 19.50 & 340.00 & 680.00 & 98.00 & 98.00 \\
\hline \multicolumn{9}{|l|}{ Brucella broth } \\
\hline F.nucleatum & 781.25 & 781.25 & 0.15 & 0.15 & 340.00 & 340.00 & 49.00 & 98.00 \\
\hline P. nigrescens & 781.25 & 781.25 & 0.15 & 0.15 & 85.00 & 170.00 & 98.00 & 98.00 \\
\hline C. perfringens & 1562.50 & 1562.50 & 2.44 & 2.44 & 680.00 & 680.00 & 98.00 & 98.00 \\
\hline B. fragilis & 3125.00 & 3125.00 & 2.44 & 2.44 & 340.00 & 680.00 & 98.00 & 98.00 \\
\hline
\end{tabular}

$\mathrm{Ca}(\mathrm{OH})_{2}$ - calcium hydroxide; Chlorhexidine - chlorhexidine digluconate; CPMC - camphorated paramonoclorophenol; Detergent castor oil plant detergent.

Table 2. MIC and MBC ranges in $\mu \mathrm{g} / \mathrm{ml}$ and number of dilutions (within parentheses) of the interval for antibacterial agents in RCM broth and Brucella broth.

\begin{tabular}{lcc}
\hline Antibacterial agents & MIC & MBC \\
\hline RCM broth & & \\
$\mathrm{Ca}(\mathrm{OH})_{2}$ & $781.2-6250.0(3)$ & $781.2-6250.0(3)$ \\
Chlorhexidine & $0.3-9.7(5)$ & $0.6-19.5(5)$ \\
CPMC & $85.0-680.0(3)$ & $340.0-680.0(1)$ \\
Castor oil detergent & $49.0-196.0(2)$ & $98.0-196.0(1)$ \\
& & \\
Brucella broth & & \\
Ca(OH) & & \\
Chlorhexidine & $781.2-3125.0(2)$ & $0.15-2.4(4)$ \\
CPMC & $0.15-2.4(4)$ & $170.0-680.0(2)$ \\
Castor oil detergent & $85.0-680.0(3)$ & 98.0 \\
\hline
\end{tabular}

\section{DISCUSSION}

In systemic infections, it is usually enough to determine the MCI, because the mechanisms of host defense complement the antibacterial action. In infected root canals, where these mechanisms are less active, it is necessary to establish the MBC and the extent of antimicrobial activity, thus the need to standardize techniques. The use of a spectrophotometer for the determination of inoculum concentration and growth readings, unlike the usual visual readings, removed any subjectivity of the evaluation.

MICs and MBCs were in agreement for most antibacterial agents for each bacteria tested separately (Table 1), mainly in supplemented Brucella broth. An exception was seen for chlorhexidine. This makes us question the need for MBC determination for antibacterial agents used in root canals as well as in systemic infections because the concentrations were almost equal.

Comparison among agents shows that chlorhexidine was efficient at the lowest concentrations for all bacteria, followed by the castor oil plant detergent, CPMC and calcium hydroxide. On the other hand, the variation of 1 to 5 dilutions in the MICs and MBCs ranges (Table 2), when the bacteria are considered together, emphasizes the varied susceptibility of the microorganisms.

The values of MICs and MBCs, varying between $0.15 \mu \mathrm{g} / \mathrm{ml}$ and $19.5 \mu \mathrm{g} / \mathrm{ml}$, demonstrated that even at low concentrations chlorhexidine can be effective and confirmed the good results obtained by others in the elimination of anaerobic bacteria $(4,10)$. It is necessary to remember, however, that the inhibition of isolated bacteria requires much lower concentrations than those necessary for associations of several bacteria (11).

Calcium hydroxide was the one and only agent for which antimicrobial activity could not be evaluated through visual reading, because all tubes suffered alteration because of changes the drugs induced, rendering 
the spectrophotometer reading indispensable. Calcium hydroxide was also the substance that needed the highest concentrations to produce the MICs and MBCs (between $781.25 \mu \mathrm{g} / \mathrm{ml}$ and $6250 \mu \mathrm{g} / \mathrm{ml}$ ). In the only report about the use of an agar dilution test with twelve different anaerobic bacteria, Suzuki (12) observed MICs in the range of 1560 to $25,000 \mu \mathrm{g} / \mathrm{ml}$, confirming our results in part.

The antimicrobial activity of calcium hydroxide in the present study is consistent with the significant results produced clinically by this agent whose effectiveness is comparable to that of chlorhexidine and CPMC (13) while it contradicts the absence of or minimal antibacterial activity on facultative or strict anaerobic bacteria observed with the calcium hydroxide paste in agar diffusion tests (13-16). This last has been ascribed to its low diffusion into agar or to the buffer capacity of artificial media, that reduces its high $\mathrm{pH}$ (16). Results equally negative, when the vehicle for calcium hydroxide was distilled water or physiological solution, were also seen in in vitro tests using dentin cylinders infected with different microorganisms $(10,17)$.

The effect on all anaerobic bacteria shown by CPMC has already been demonstrated by Siqueira Jr. et al. (15) in agar diffusion tests. CPMC was used in the liquid form, which presents a higher antibacterial effect than the vapour form (18). In vapour form, MICs and MBCs should be higher than the results presented here.

In the literature, there are comparisons among these three substances with divergent results in terms of their antimicrobial activities on strict anaerobic bacteria species, using different methodologies. In the specific case of the agar diffusion tests used by many authors, there is a conceptual mistake, because they are not suitable for anaerobic microorganisms (8). In addition, the authors make comparisons between drugs taking into account the size of the zones of inhibition, which is incorrect, because they are dependent on a series of factors.

The MIC and MBC values obtained for the castor oil plant detergent were lower than those of CPMC and calcium hydroxide. In the only report on the use of that substance for irrigation in the treatment of teeth with pulp necrosis, the effect was similar to that of $0.5 \%$ sodium hypochlorite for the elimination of root canal infection (7). According to the authors (7), no case showed any post-operative symptomatology, exu- date or edema and the clinical and radiographic followup indicated periapical repair. This result is promising for intracanal medications because, together with the antimicrobial activity demonstrated in the present study, its biocompatibility has already been proven (6). Also, castor oil plant polymers experimentally used in bone defects produced in animals were shown to be bone inducers and non-toxic $(19,20)$.

In the present study, we observed that Clostridium perfringens and Bacteroides fragilis were the bacteria with the highest MICs and MBCs. Coincidentally, these microorganisms are commonly resistant to antibiotics and used as controls in susceptibility testing.

MBC is extremely method-dependent, and the use of two different culture broths, in which the bacteria do not exhibit the same growth and whose interaction with the antibacterial agents can differ, was an opportunity for this evaluation. We observed, however, that except for chlorhexidine, the lower growth seen in Brucella broth did not interfere excessively in the results, with MBCs usually being the same or one lower concentration in that broth. The bacterial resistance given by MICs and MBCs was not associated to the growth exhibited by the bacteria in the two broths, because all bacteria exhibited similar growth compared to the OD of the positive controls.

Even considering that in vitro studies are accomplished with isolated bacteria, while endodontic infections are usually mixed with complex microbial interactions that can interfere in the action of different antibacterial agents, this study allowed an objective quantitative evaluation of the action of the different agents and opens the possibility for the use of a new product. This study also suggests the evaluation of associations of these antibacterial agents to determine a possible synergic action.

\section{ACKNOWLEDGMENT}

We acknowledge FAPESP (Fundação de Amparo a Pesquisa do Estado de São Paulo - Brazil) for the financial support of the study.

\section{RESUMO}

Ferreira CM, Rosa OPS, Torres SA, Ferreira FBA, Bernardinelli N. Atividade antimicrobiana de agentes antibacterianos utilizados em Endodontia sobre bactérias anaeróbias estritas. Braz Dent J 2002;13(2):118-122. 
Foi avaliado in vitro a capacidade antimicrobiana de substâncias utilizadas como agentes antimicrobianos (solução de hidróxido de cálcio $10 \%$, paramonoclorofenol canforado - PMCC, digluconato de clorexidina $2 \%$ e detergente de mamona $10 \%$ ) sobre bactérias anaeróbias (Fusobacterium nucleatum ATCC 25586, Prevotella nigrescens ATCC 33563, Clostridium perfringens ATCC 13124 e Bacteroides fragilis ATCC 25285), utilizando-se a técnica da diluição em caldo. Para a determinação das concentrações inibitória e bactericida mínimas (CIM e CBM), dois caldos, Reinforced Clostridial Medium (RCM) e Brucella suplementado, inóculo padronizado e diluições seriadas foram utilizados. Todos os agentes antimicrobianos apresentaram atividade antimicrobiana, variando para as diferentes espécies bacterianas, não havendo diferença entre os caldos utilizados. $\mathrm{O}$ digluconato de clorexidina demonstrou a melhor eficiência, com as menores CIMs, seguido pelo detergente de mamona, PMCC e hidróxido de cálcio. C. perfringens e $B$. fragilis foram as espécies mais resistentes aos agentes.

Unitermos: endodontia, microbiologia, bactérias anaeróbias, agentes antimicrobianos.

\section{REFERENCES}

1. Sundqvist G. Associations between microbial species in dental root canal infections. Oral Microbiol Immunol 1992;7:257-262.

2. Lana MA, Ribeiro-Sobrinho AP, Stheling R, Garcia GD, Silva BK, Hamdan JS, Nicoli JR, Carvalho MA, Farias LM. Microorganisms isolated from root canals presenting necrotic pulp and their drug susceptibility in vitro. Oral Microbiol Immunol 2001;16:100-105.

3. Baumgartner JC, Watkins BJ, Bae KS, Xia T. Association of black-pigmented bacteria with endodontic infections. J Endod 1999;25:413-415.

4. Leonardo MR, Tanomaru Filho M, Silva LA, Nelson Filho P, Bonifácio $\mathrm{KC}$, Ito IY. In vivo antimicrobial activity of $2 \%$ chlorhexidine used as a root canal irrigating solution. J Endodon 1999;25:167-171.

5. Siqueira Jr JF. Effectiveness of formocresol and calcium hydroxide camphorated paramonochlorophenol paste in preventing entire root canal recontamination by bacteria from saliva. An in vitro study. Braz Endod J 1997;2:23-25.

6. Mantesso A. In vitro evaluation of a new intracanal irrigating solution derived from Ricinus communis. Anais da XVI Reunião
Anual da SBPqO 2000;1:18

7. Ferreira CM, Bonifácio KC, Fröner IC, Ito IY. Evaluation of the antimicrobial activity of three irrigating solutions in teeth with pulpal necrosis. Braz Dent J 1999;10:15-21.

8. Hindler JA, Howard BJ, Keiser JF. Antimicrobial agents and antimicrobial susceptibility testing. In: Howard BJ. Clinical and Pathogenic Microbiology. 2nd ed. St.Louis: Mosby, 1994, Chapter 9.

9. Sutter VL. Wadsworth anaerobic bacteriology manual. 4th ed. Belmont: Star, 1985.

10. Heling I, Sommer M, Steinberg D, Friedman M, Sela MN. Microbiological evaluation of the efficacy of chlorhexidine in a sustained-release device for dentine sterilization. Int Endod $\mathrm{J}$ 1992;25:15-19.

11. Kinniment SL, Wimpenny JW, Adams D, Marsh PD: The effect of chlorhexidine on defined, mixed culture oral biofilms grown in a novel model system. J Appl Bacteriol 1996;81:120-125.

12. Suzuki K. Antimicrobial effect of calcium hydroxide on bacteria isolated from infected root canals. Dentistry in Japan 1999;35:4347.

13. Barbosa CA, Gonçalves RB, Siqueira Jr JF, De Uzeda M. Evaluation of the antibacterial activities of calcium hydroxide, chlorhexidine, and camphorated paramonochlorophenol as intracanal medicament. A clinical and laboratory study. J Endodon 1997;23:297-300.

14. Difiore PM, Peters DD, Setterstrom JÁ, Lorton L. The antibacterial effects of calcium hydroxide apexification pastes on Streptococcus sanguis. Oral Surg Oral Med Oral Pathol 1983;55:91-94.

15. Siqueira Jr JF, Lopes HP, Uzeda M. Atividade antibacteriana de medicamentos endodônticos sobre bactérias anaeróbias estritas. Rev Assoc Paul Cir Dent 1996;50:326-331.

16. Siqueira Jr JF, Gonçalves RB. Antibacterial activities of root canal sealers against selected anaerobic bacteria. J Endodon 1996;22:79-80.

17. Siqueira Jr JF, Uzeda M. Disinfection by calcium hydroxide pastes of dentinal tubules infected with two obligate and one facultative anaerobic bacteria. J Endodon 1996;22:674-676.

18. Haapasalo M, Orstavik D. In vitro infection and disinfection of dentinal tubules. J Dent Res 1987;66:1375-1379.

19. Ignacio $H$. Utilização do cimento derivado do polímero da mamona no preenchimento da falha óssea. Estudo experimental em coelhos. [Master's thesis]. Ribeirão Preto: Faculdade de Medicina de Ribeirão Preto, USP, 1995.

20. Araújo CACA, Brentegani LG. Cronologia do reparo alveolar do rato após implante de Ricinus comunis. Anais da XIII Reunião Anual da SBPqO 1996;1:120. 